\author{
LIDIA ZACHARKO \\ ORCID: 0000-0002-3799-5502 \\ Uniwersytet Śląski \\ lidia.zacharko@us.edu.pl
}

\title{
Administracja publiczna zarządzana nowocześnie — kilka refleksji
}

\begin{abstract}
Abstrakt: Celem artykułu jest próba pokazania wyzwań, które stoją przed administracją publiczną w zakresie zarządzania. Specyfika świadczonych usług wymusza właściwy, jak też uporządkowany sposób działania, którego głównym celem powinna być jakość. Klient jest najważniejszą osobą w każdej organizacji. Zarządzanie jakością w administracji implikuje wdrożenie nowoczesnych technik i metod działania, takich jak: benchmarking, benchlearning, reengineering, outsourcing, czy regranting.
\end{abstract}

Słowa kluczowe: zarządzanie jakością, benchmarking, benchlearning, outsourcing, zarządzanie wiedzą, organizacja inteligentna.

\section{Wstęp}

Jak pisał E. Knosala: „Nie ma sfery życia człowieka, w której nie byłaby obecna administracja publiczna wypełniając swoje zadania świadczące, planujące oraz ingerencje"1. Administracja publiczna jest makrosystemem organizacyjnym, złożonym z subsystemów (ogniw). Harmonijne ich współdziałanie jest warunkiem efektywnego zaspokajania potrzeb publicznych ${ }^{2}$.

P. Lisowski zaznacza, że niepomijalność podmiotów administracji publicznej i ich organów oraz zasięg i intensywność ich oddziaływania na życie społeczne

${ }^{1}$ E. Knosala, Zadania publiczne, formy organizacyjno prawne ich wykonywania i nowe pojęcia - zakres niektórych problemów do dyskusji nad koncepcja systemu prawa administracyjnego, [w:] Koncepcja systemu prawa administracyjnego, red. J. Zimmermann, Kraków 2007, s. 118.

2 E. Knosala, Prawne uktady sterowania w administracji publicznej, Katowice 1998, s. 11. 
podkreślają rangę problematyki organizacji prawnej administracji ${ }^{3}$. Jak zaznaczał J. Boć - organizacji inteligentnej, ponieważ obejmuje ludzi, dotyczy ludzi i jest realizowana przez ludzi, bo tylko ludzie tworzą administrację i są adresatami działań administracji ${ }^{4}$.

Administracja publiczna $\mathrm{w}$ demokratycznym państwie prawa wypełnia doniosłą misję społeczną. Jak słusznie wskazuje S. Fundowicz, nie ma sprawnego państwa bez dobrej administracji z wykwalifikowanymi, bezstronnymi i obiektywnymi administrującymi. Sprawne państwo z poszanowaniem zasady pomocniczości (zbliżającej administrację do administrowanych) ma traktować i wspierać swoich obywateli według jednakowej, słusznej i sprawiedliwej miary, stwarzając im równe szanse i dbając o ich godność 5 .

W administracji publicznej akcentuje się trzy podstawowe czynniki: skuteczność, legalizm oraz podmiotowość klientów; mniej wspomina się o efektywności działania i zysku ${ }^{6}$. Zorientowanie działań na klienta może przyczynić do poprawy jakości usług oraz ich lepszego dostosowania do zróżnicowanych potrzeb ${ }^{7}$, co implikuje wdrożenie nowoczesnych metod i technik zarządzania, to jest systemu zarządzania jakością, zarządzania wiedzą (knowledge management), czy organizacji inteligentnej.

\section{Istota zarządzania przez jakość w administracji publicznej}

Przełom XX i XXI wieku to wzrost znaczenia funkcji jakości w życiu społeczno-gospodarczym człowieka. Jakość w zarządzaniu stała się najważniejszą ideą. Zarządzanie jakością to działania z zakresu zarządzania, które decydują o polityce jakości, celach i odpowiedzialności, a także ich realizacji w ramach systemu jakości za pomocą takich środków, jak: planowanie jakości, sterowanie jakością, zapewnienie jakości i doskonalenie jakości ${ }^{8}$. Obecnie ma ono postać

3 P. Lisowski, Organizacja prawna administracji wobec przemian cywilizacyjnych, [w:] Wplyw przemian cywilizacyjnych na prawo administracyjne i administracje publiczna, red. J. Zimmermann, P. Suwaj, Warszawa 2013, s. 45.

4 J. Boć, Ku administracji jako administracji inteligentnej, [w:] Profesjonalizm w administracji publicznej, red. A. Dębicka, M. Dmochowski, B. Kudrycka, Białystok 2004, s. 31.

5 S. Fundowicz, Człowiek i administracja publiczna, [w:] Prawość i godność. Księga pamiatkowa w 70. rocznice urodzin Profesora Wojciecha Eaczkowskiego, red. S. Fundowicz, F. Rymarz, A. Gomułowicz, Lublin 2003, s. 107.

6 W. Zieliński, Misja administracji publicznej a motywy inicjowania zmian, „Przegląd Organizacji” 2007, nr 11, s. 19.

${ }^{7}$ A. Zalewski, Nowe zarzadzanie publiczne w polskim samorzadzie terytorialnym, Warszawa 2007, s. 79.

8 A. Hamrol, W. Mantura, Zarzadzanie jakościa. Teoria i praktyka, Warszawa 1998, s. 98 n. 
całościowej filozofii zarządzania zwanej kompleksowym zarządzaniem jakością TQM (total quality managemnet), jej celami jest zaspokojenie wymagań klientów przez ciągłe doskonalenie. W zarządzaniu jakością klient jest kluczowym pojęciem, zarówno wewnętrzny (pracownicy), jak i zewnętrzny. W dobie gospodarki rynkowej organizacje, w tym administracja publiczna, w swoich działaniach muszą dostosować się do potrzeb klientów9.

TQM zawiera większość nowoczesnych metod i technik zarządzania; łączy je w cały, spójny, uniwersalny model. Zarządzanie jakością połączone jest z zarządzaniem zasobami ludzkimi. Polityka TQM uznaje przywództwo za jeden z najważniejszych czynników i przyjmuje, że od jakości pracy przełożonych uzależniona jest efektywność działań.

Jak podkreślają A.W. Dahlberg, D.W. Connel i J. Landrum, jakość przywództwa jest kluczowym elementem satysfakcjonującym otoczenie pracy ${ }^{10}$. W relacjach podwładny-przełożony silniejszą stroną jest z pewnością przełożony, niemniej w administracji dużą rolę odrywa personel pierwszego kontaktu z klientem.

Zdaniem H. Drummonda zachowania personelu mające wpływ na postrzeganie jakości usług powinny być niezawodne, odpowiedzialne, kompetentne, komunikatywne, grzeczne, wiarygodne; poza tym ważne jest rozpoznanie indywidualnych potrzeb klienta czy cechy wymierne, wyposażenie biur i sposóbich zaprojektowania ${ }^{11}$.

Wdrażanie systemu TQM wiąże się z prowadzeniem przez kierownictwo polityki długofalowej, długookresowej, która będzie obowiązywać wszystkich pracowników. Należy zatem organizować wielostronne badania potrzeb klientów, określać wymogi dotyczące jakości, promować odpowiedzialność za wysoką jakość (opracować system samokontroli i motywacji pracowników), rozwijać ocenę jakości usług, czyli monitorować proces jakości, zmieniać złe procedury czy podejmować działania korygujące. TQM, jego stosowanie, może okazać się sukcesem, przynieść wymierne korzyści tylko wówczas, gdy potraktuje się go jako proces ciągły, a nie incydentalny, nigdy niekończący się ${ }^{12}$.

Drogą do zrealizowania TQM w administracji publicznej stają się normy ISO. Normy z serii ISO są wydawane przez Międzynarodową Organizację Normalizacyjną (ISO - International Organisation for Standardisation). Jej celem jest promowanie i tworzenie międzynarodowych standardów w różnych dziedzinach działalności. Normy ISO nie są normami dotyczącymi wyrobów, lecz odnoszącymi się do sposobu zarządzania ${ }^{13}$. Normy ISO to wyraz projakościowego

9 M. Hammer, J. Champy, Reengineering w przedsiębiorstwie, Warszawa 1996, s. 38.

10 A.W. Dahlberg, D.W. Connell, J. Landrum, Budujac nowa firme - w dlugim okresie, [w:] Organizacja przyszłości, red. F. Hesselbein, M. Goldsmith, L. Beckhard, Warszawa 1998, s. 400 n.

11 H. Drummond, W pogoni za jakościa, Warszawa 1998, s. 99.

12 Ibidem, s. 55 n.

13 Przez długi czas normy ISO stanowiły: ISO 8402 - Zarządzanie jakością i zapewnienie jakości. Terminologia dotycząca pojęć z zakresu jakości; ISO 9000 - Zarządzanie jakością i zapewnienie jakości. Wytyczne wyboru i stosowania, polski odpowiednik PN-EN ISO 9000-2015; 
i ciągłego doskonalenia jakości w organizacji; są pomocne w tworzeniu przez organizację systemu jakości ${ }^{14}$. Najbardziej znaną normą jest norma ISO-9001, której proces nowelizacji zakończył się we wrześniu 2015 roku.

Międzynarodowa Organizacja Normalizacyjna 15 września 2015 roku opublikowała nową wersję norm ISO 9001:2015. Zastąpiła ona wersję dotychczasową (ISO 9001:2008), której ważność upłynęła 14 września 2018 roku. Cechą przyjętego w organizacji systemu jakości powinny być ciągłe zmiany organizacyjne, mające usprawnić system obiegu informacji, zadań i odpowiedzialności do wymagań otoczenia ${ }^{15}$.

\section{Nowoczesne metody i techniki w realizacji zadań projakościowych}

Do realizacji zadań projakościowych w organizacjach, w tym w administracji publicznej, służą techniki, metody jako instrumenty przydatne do osiągnięcia zamierzonych celów. Kluczową rolę odgrywają tu między innymi: benchmarking, benchlearning, reengineering, outsourcing czy regranting ${ }^{16}$.

Współczesna nauka organizacji i zarządzania proponuje różne metody i koncepcje będące wsparciem realizacji przez organizację, w tym administrację celów i zadań, względem zmieniającego się otoczenia ${ }^{17}$. Jedną z tych metod jest metoda benchmarkingu, która ma na celu usprawnienie procesów pracy w administracji publicznej. Benchmarking to nowa metoda wspomagająca zarządzanie, która powstała w latach dziewięćdziesiątych XX wieku w Stanach Zjednoczonych.

ISO 9001 — systemy zarządzania jakością — wymagania, polski odpowiednik PN-EN ISO 9001-2015; ISO 9004-2009 — zarządzanie mające na celu osiągnięcie trwałego sukcesu organizacji, polski odpowiednik PN-EN ISO 9004-2010; ISO 19011-2011 — wytyczne dotyczące systemów audytowania systemów zarządzania, polski odpowiednik PN-EN ISO 19011-2012, która zastąpiła wersję z 2003 roku. W wyniku zmian w rozwoju społeczno-gospodarczym i technicznym normy ISO podlegały modyfikacji, dostosowując się do nowych realiów. W 2000 roku nastąpiła ich istotna aktualizacja, położono nacisk na podejście procesowe i ciągły rozwój. Zob. B. Sankowski, ISO jako narzędzie zarządzania, „Problemy Jakości” 2015, nr 3, s. 15-16.

14 Ibidem, s. 15.

15 L. Zacharko, Dylematy nauki administracji — Problemy dyskusyjne, [w:] Stan i kierunki rozwoju nauk administracyjnych, red. A. Błaś, J. Boć, Wrocław 2014, s. 80.

16 Szerzej na ten temat J. Blicharz, L. Zacharko, Globalizm a personalizm wobec administracji publicznej. Studium prawno-administracyjne, Wrocław 2019, s. 67-79.

17 B. Nogalski, K. Zduńczyk, Benchmarking jako przejaw kultury organizacyjnej, [w:] Kultura organizacyjna - duch organizacji, red. B. Nogalski et al., Bydgoszcz 1988, s. 194 n.; a także B. Nogalski, Benchmarking metoda usprawniania procesów pracy administracji samorzadowej, [w:] Prawne i finansowe aspekty funkcjonowania samorzadu terytorialnego, t. 1. Prawo samorzadowe $i$ administracyjne, red. S. Dolata, Opole 2000, s. 253-266 i cyt. literatura. 
Zdaniem B. Nogalskiego i Z. Zduńczyka benchmarking ma następujące atrybuty: systematyczność działania, uczenie się, poszukiwanie najlepszych możliwych rozwiązań ${ }^{18}$.

W literaturze przedmiotu wskazuje się na dwa zasadnicze modele benchmarkingu, to jest wewnętrzny, który opiera się na porównaniach względem tej samej organizacji (jednostki organizacyjne), i zewnętrzny, tak zwany konkurencyjny, dzięki któremu procesy pracy w danej organizacji mogą być porównywalne z procesami stosowanymi przez inne organizacje, przy czym porównywać można wyłącznie procesy i rzeczy podobne ${ }^{19}$.

Jak podnosi B. Nogalski, benchmarking daje bardzo dobre poznanie swojej organizacji i jej problemów oraz umożliwia wprowadzanie odpowiednich, skutecznych zmian ${ }^{20}$.

W metodzie benchmarkingu można wyróżnić następujące etapy: wybór przedmiotu, to jest obszarów wymagających poprawy, przeprowadzenie wewnętrznych badań w celu określenia obecnej praktyki i wyników, wybór porównywalnego obszaru, zebranie danych z zewnątrz; analiza danych, określenie potencjału poprawy, utrwalenie programu poprawy ${ }^{21}$.

Inni, jak na przykład T. Bendell czy L. Boulter, zaznaczają, że benchmarking musi mieć charakter systematyczny, czyli po ostatnim etapie musi nastąpić powrót do etapu pierwszego - wówczas mamy do czynienia z procesem ciągłej poprawy, co jest naczelną ideą w zarządzaniu jakością 22 .

Warto w tym miejscu zwrócić uwagę na benchlearning, który został wprowadzony decyzją Parlamentu Europejskiego i Rady nr 573/2014/UE w sprawie wzmocnionej współpracy między publicznymi służbami zatrudnienia opartymi na analizie porównawczej (gromadzenie danych, ich walidowanie, konsolidowanie, ocenianie) i działaniami dotyczącymi wzajemnego uczenia się 23 .

Reengineering jest innowacyjną metodą poprawy — pozwala rozpoczynać procesy od nowa. Reengineering stara się dokonać głównych zmian dotyczących organizacji nie poprzez usprawnianie procesów, ale odrzucenie dotychczasowych i zastąpienie ich nowymi, na przykład informatyzacja procesów administrowania wymusza istotne zmiany w obiegu dokumentów i informacji w administracji. Nowoczesna technologia to podstawa reengineeringu. Wśród cech tej metody wymie-

18 B. Nogalski, K. Zduńczyk, op. cit.

19 Ibidem, s. $256 \mathrm{n}$.

20 Ibidem, s. 264.

21 T. Bendell, L. Boulter, Benchmarking, Kraków 1999, s. 83; B. Karlof, S. Ostblom, Benchmarking, Warszawa 1995, s. 66.

22 T. Bendell, L. Boulter, op. cit.

23 Decyzja Parlamentu Europejskiego i Rady 573/2014/UE z dnia 15 maja 2014 roku, Dz.Urz. UE L 159 z dnia 28 maja 2014 roku. 
nia się chociażby uproszczenie procedur ${ }^{24}$, decentralizację władzy, zmianę ról kierownictwa w organizacji, spłaszczenie struktur organizacji ${ }^{25}$.

Reengineeringowi towarzyszy często outsourcing, czyli wykorzystanie zasobów zewnętrznych organizacji, to jest zlecanie zadań publicznych podmiotom spoza aparatu administracji publicznej, tworząc skuteczny mechanizm przekazywania między innymi zadań publicznych organizacjom pozarządowym, które mogą być przez nie wykonywane (zasada pomocniczości) ${ }^{26}$. Ponadto, przekazując zadania na drodze umownej, państwo wspiera także finansowo rozwój instytucji obywatelskich, co po pewnym czasie prowadzi do obniżenia kosztów jego funkcjonowania (zasada efektywności) ${ }^{27}$.

Kluczową zasadą do kontraktowania zadań publicznych jest zasada partnerstwa, która oznacza prawo organizacji pozarządowych do współdefiniowania

${ }^{24} \mathrm{~W}$ dyskursie naukowym podnosi się, że należy odrzucić koncepcję organizacji wyspecjalizowanej zadaniowo, ale należy zająć się procesami. Każdy proces można opisać trzema parametrami: jakość, czas reagowania (realizacji) i koszty. Zob. R.S. Kaplan, R. Cooper, Zarządzanie kosztami i efektywnościa, Kraków 2000, s. 62-65.

25 M. Hammer, J. Champy, op. cit., s. 50 n.

${ }^{26}$ Szerzej zob. E. Leś, Od filantropii do pomocniczości. Studium porównawcze rozwoju i dziatalności organizacji społecznych, Warszawa 2000; J. Blicharz, Znaczenie zasady subsydiarności $w$ kontekście przekazywania wykonywania zadań administracji publicznej organizacjom pozarzadowym, „Przegląd Prawa i Administracji” 76, 2007, s. 7-8; A. Pakuła, Samorząd terytorialny a działalność pożytku publicznego, [w:] Samorząd terytorialny III Rzeczypospolitej Polskiej. Materiały z konferencji z okazji 15-lecia samorzadu terytorialnego w III Rzeczypospolitej, red. J. Korczak, Wrocław 2005, s. 95 n.; Z. Wejcman, O pomocniczości i innych fundamentalnych zasadach wspótpracy, [w:] Partnerstwo $w$ praktyce. System wspótpracy samorządów lokalnych z organizacjami pozarządowymi, red. M. Bielawski, A. Jakimowicz, Elbląg 2007, s. 8 n.; J. Blicharz, Komentarz do ustawy o działalności pożytku publicznego i wolontariacie, [w:] Ustawa o działalności pożytku publicznego $i$ wolontariacie. Ustawa o spółdzielniach socjalnych. Komentarz, red. J. Blicharz, Warszawa 2012; I. Czaja-Hliniak, Europejska Karta Samorząu Lokalnego fundamentem wspótpracy jednostek samorzadu terytorialnego z podmiotami niepublicznymi, [w:] Europejska Karta Samorzadu Lokalnego a prawo samorządu terytorialnego, red. M. Ofiarska, Szczecin 2015, s. 39-53; L. Zacharko, A. Zacharko, Organizacje pozarządowe, jako instytucjonalne formy nacisku na decydentów politycznych, „Przegląd Prawa Publicznego” 2016, nr 6-7, s. 44-55; J. Blicharz, Działalność organizacji pozarzadowych (organizacji pożytku publicznego) w ujęciu historycznym, [w:] Prawo organizacji pozarzadowych (organizacji pożytku publicznego). Działalność gospodarcza organizacji pozarzadowych, red. J. Blicharz, L. Zacharko, Racibórz 2017, s. 27 i cyt. tam literatura; J. Wróblewska-Jachna, Misja organizacji pozarządowych w społeczeństwie obywatelskim, [w:] Prawo organizacji pozarzqdowych..., s. 47-61 i cyt. tam literatura; D. Cendrowicz, Pomocniczość, jako zasada organizacji pomocy społecznej w samorzadzie terytorialnym, [w:] Sposoby realizacji zadań publicznych, red. B. Dolnicki, Warszawa 2017, s. 148-159; A. Miruć, Zasada pomocniczości jako podstawa realizacji zadań publicznych z zakresu pomocy społecznej, [w:] Sposoby realizacji zadań..., s. 472-485; D. Fleszer, Realizacja zadań publicznych przez organizacje pozarzadowe. Studium administracyjnoprawne, Sosnowiec 2018, s. 97-126.

27 L. Zacharko, Uspołecznienie procesu administrowania - przyczynek do dyskusji, [w:] Nowe problemy badawcze w teorii prawa administracyjnego, red. J. Boć, A. Chajbowicz, Wrocław 2009 , s. 528-529.

Prawo 331, 2020

(C) for this edition by CNS 
zadań publicznych oraz przyjmowanie na siebie obowiązku informowania o planowanych i podejmowanych działaniach ${ }^{28}$.

Jak słusznie zauważa A. Barczewska-Dziobek, istota partnerstwa polega na specyficznym rodzaju zależności, którego treścią jest uczestnictwo i współdziałanie we wspólnym celu. Partnerstwem publiczno-społecznym można nazwać więzi prawne ukształtowane na podstawie stosunków w obrębie prawa administracyjnego między podmiotami partnerstwa na zasadach dobrowolności, równorzędności i wzajemności w celu realizacji zadań administracji publicznej ${ }^{29}$.

Niektóre cele z zakresu administracji publicznej można zatem łatwiej i szybciej zrealizować dzięki organizacji pozarządowej - zwłaszcza tam, gdzie potrzebna jest współpraca z ludnością zainteresowaną bezpośrednio określonymi działami administracji ${ }^{30}$.

W problematyce innowacyjnych rozwiązań w zakresie kontraktowania usług społecznych na uwagę zasługuje model zadaniowy, tak zwany podwójny outsourcing (regranting), wprowadzony zmianą ustawy o działalności pożytku publicznego $\mathrm{i}$ wolontariacie z dnia 22 stycznia 2010 roku $^{31}$. Artykuł 16 ust. 7 ustawy stanowił, że organizacje pozarządowe lub podmioty wymienione w art. 3 ust. 3, z którymi organ administracji publicznej zawarł umowę, o której mowa w ust. 1, mogą zlecić realizację zadania publicznego wybranym, w sposób zapewniający jawność, uczciwą konkurencję, organizacjom pozarządowym lub podmiotom wymienionym w art. 3 ust. 3, niebędącym stronami umowy, odpowiednio o wsparcie realizacji zadania publicznego lub o powierzenie zadania publicznego.

Zmiana ustawy o działalności pożytku publicznego i wolontariacie z dnia 5 sierpnia 2015 roku $^{32}$, która weszła w życie 9 listopada 2015 roku, uchyliła z kolei ust. 7 art. 16 wymienionej ustawy, dokonując jednocześnie zmiany w treści ust. 4, stanowiącego, że zadanie publiczne nie może być realizowane przez podmiot niebędący stroną umowy, o której mowa w ust. 1, chyba że umowa ta zezwala na wykonanie określonej części zadania przez taki podmiot ${ }^{33}$. W wyniku regrantingu następuje zatem redystrybucja środków, a zadanie publiczne jest realizowane przez inną organizację, która nie jest stroną umowy ${ }^{34}$.

28 Prawne regulacje działania organizacji pozarzadowych, red. L. Irisha, K. Simon, R. Kushena, Warszawa 1999, s. 95.

29 A. Barczewska-Dziobek, Partnerstwo publiczno-prywatne, jako zasada w prawie administracyjnym, Rzeszów 2019, s. 20.

30 Prawo administracyjne, red. J. Boć, Wrocław 2000, s. 161.

31 Dz.U. z 2010 r. Nr 28, poz. 446. Szerzej na temat zmian wprowadzonych A. Siennicka, Nowelizacja ustawy o działalności organizacji pożytku publicznego $i$ wolontariacie, „Biuletyn” 2010, nr 1, s. 9.

32 Dz.U. z 2015 r. poz. 1339.

33 Tekst jedn. Dz.U. z 2019 r. poz. 688 ze zm.

34 www.ling.pl słownik polsko-angielski. Pojęcie regrantingu przywędrowało do Polski w latach osiemdziesiątych i dziewięćdziesiątych XX wieku. Regranting jako określenie angielskie dotyczy mechanizmu zlecania zadania, w ramach którego środki otrzymywane w formie dotacji (grantu) 
Powyższe zmiany ustawy o działalności pożytku publicznego i wolontariacie kreują nowy model realizacji usług społecznych, modernizując system ich dostarczania.

W literaturze przedmiotu podkreśla się, że w wyniku regrantingu po stronie jednostki samorządu terytorialnego następuje między innymi: zmniejszenie obciążeń organizacyjnych związanych z przeprowadzeniem konkursów, skuteczne dotarcie z ofertą do różnych środowisk, lepszą jakość składanych ofert, efektywniejsze wykorzystanie środków oraz pomnożenie środków dzięki wkładowi operatora i grantobiorców. Po stronie organizacji pozarządowej z kolei korzyści mogą dotyczyć: uproszczenia procedur o dotację, zdobycia większej ilości środków na dotację ${ }^{35}$.

Należy podzielić stanowisko prezentowane w literaturze przedmiotu, ponieważ zakres zlecania nie może obejmować kompetencji kluczowych organów samorządu terytorialnego, związanych z prowadzeniem postępowania i wydawania decyzji administracyjnych ${ }^{36}$ - co znalazło odzwierciedlenie w rozwiązanych prawnych.

Zarządzenie jakością $\mathrm{w}$ administracji publicznej wymaga także wdrożenia zintegrowanego podejścia do identyfikowania i dzielenia się zasobami informacyjnymi, które obejmują bazy danych, dokumenty, polityki, sformalizowane procedury, jak też ekspertyzy (zarządzanie wiedzą) ${ }^{37}$.

W dobie informatyzacji, wzrostu konkurencyjności i przedsiębiorczości instytucji oraz dążenia do poprawy jakości usług coraz większą rolę odgrywa wiedza. Jak podkreśla się w literaturze, rozwój koncepcji zarządzania wiedzą nastąpił w latach dziewięćdziesiątych XX wieku. Należy w tym miejscu wspomnieć o pracach A. Kuklińskiego ${ }^{38}$, B. Wawrzyniaka ${ }^{39}$, A. Kowalczyka ${ }^{40}$, W. Grudzewskiego, I. Hejduk ${ }^{41}$, B. Nogalskiego ${ }^{42}$ czy A. Jashapara ${ }^{43}$.

przez jeden podmiot są $\mathrm{w}$ dalszej kolejności przekazywane innym podmiotom. W ramach regrantingu jednostki samorządu terytorialnego same nie organizują konkursów i nie przyznają dotacji, ale znajdują partnera (operatora) — organizację pozarządową — która w ich imieniu zajmuje się przygotowaniem konkursu oraz przyznaniem dotacji i jej rozliczeniem. Zob. regranting.filantropia. org.pl/archiwum/czym-jest-regranting (dostęp: 10.11.2019).

35 Szerzej zob. M. Arczewska, Raport z badania potrzeb i możliwości regrantingu w ramach projektu ,Regranting” jako sposób zwiększenia-zakresu, skali i efektywności realizacji zadań publicznych przez organizacje pozarzadowe w gminie i powiecie, Warszawa 2012.

36 J. Korczak, A. Miruć, Outsourcing komunalny na rzecz organizacji pożytku publicznego $w$ sferze pomocy społecznej $w$ świetle najnowszych uregulowań prawnych, [w:] Prawne aspekty prywatyzacji, red. J. Blicharz, Wrocław 2012, s. 153 n.

37 The Blackwell Encyclopedic Dictionary of Operations Management, red. N. Snack, Oxford 1998, s. 156 n.

38 Gospodarka oparta na wiedzy. Wyzwania dla Polski XXI wieku, red. A. Kukliński, Warszawa 2001.

39 Zarzadzanie wiedza w przedsiębiorstwie, red. B. Wawrzyniak, Warszawa 2003.

40 A. Kowalczyk, B. Nogalski, Zarządzanie wiedzą. Koncepcje i narzędzia, Warszawa 2007.

41 W. Grudzewski, I. Hejduk, Zarządzanie wiedza w przedsiębiorstwie, Warszawa 2004.

42 A. Kowalczyk, B. Nogalski, op. cit.

43 A. Jashapara, Zarzadzanie wiedza, Warszawa 2006. 
Zarządzanie wiedzą w organizacjach, w tym w administracji publicznej, składa się z pięciu zasadniczych etapów: odkrywania, generowania, wartościowania, upowszechniania oraz wykorzystania wiedzy ${ }^{44}$. Wiedza powinna być rozpatrywana wieloaspektowo w różnych procesach zarząazania organizacją. Proces zarządzania wiedzą powinien być ukierunkowany nie tylko na gromadzenie, korzystanie z danych, które ma organizacja, oraz tych pochodzących z jej otoczenia ${ }^{45}$.

Jak podkreśla M. Morawski, wiedza jest kategorią dynamiczną, nie statystyczną. Wiedza stale ewoluuje, rozprzestrzenienia się w obrębie i na zewnątrz organizacji. W systemie zarządzania wiedzą ważne są cele, ludzie, technologia, struktura organizacyjna i kultura organizacyjna ${ }^{46}$.

Zarządzenie wiedzą należy odróżnić od procesów informacyjnych w organizacji, ponieważ informacja jest jedynie pewną kategorią wiedzy. Zarządzanie informacją jest etapem początkowym (wstępnym) do budowania systemu zarządzania wiedzą ${ }^{47}$. Zarządzanie wiedzą jest podstawą do inteligentnej działalności organizacji, to jest opartej na wiedzy, która ulepsza swoje procesy, zmienia się w zależności od potrzeb otoczenia. Wiedza jest podstawowym zasobem inteligentnej organizacji, która ma charakter twórczy i innowacyjny.

W literaturze przedmiotu podkreśla się, że wiedza, umiejętności i zachowanie personelu mają decydujący wpływ na inteligentne działanie organizacji. Inteligentnie działająca organizacja to organizacja, która ma następujące cechy: wiedza jest dostępna i efektywnie wykorzystywana w organizacji, zapewnia rozwój i kulturę wewnątrz organizacji, promuje jakość wiedzy, dostarcza wiedzę pracownikom, ułatwia im skuteczne i inteligentne działanie ${ }^{48}$.

Zarządzana nowocześnie administracja publiczna wymaga jednak dobrego prawa. Zdaniem Z. Duniewskiej złe prawo dezorganizuje i wypacza państwo, rodzi dezaprobatę, skłania do nieposłuszeństwa i buntu. Sprawne państwo i dobre prawo służą wspólnocie, wpływają na poprawę jakości jej życia, wspierają i motywują inicjatywność społeczną ${ }^{49}$.

W literaturze przedmiotu od dłuższego czasu prowadzony jest dyskurs naukowy stanu prawa administracyjnego, jego niestabilności, braku przejrzystości,

44 A. Kowalczyk, B. Nogalski, op. cit., s. 15.

45 J. Blicharz, L. Zacharko, op. cit., s. 75.

46 M. Morawski, Zarzadzanie wiedza - ujęcie systemowe, „Organizacja i Kierowanie” 2006, nr 4, s. 56, 58 .

47 A. Kowalczyk, B. Nogalski, op. cit.

48 M. Dolińska, Zarządzanie wiedza w uczącej się organizacji, „Organizacja i Kierowanie” 2000, nr 4, s. 16 i cyt. tam literatura, między innymi J.D. Teese, G. Pisano, A. Shuen, Dynamic capabilities and strategic management, „Strategic Management Journal” 18, 1997, nr 7, s. 509-533; K.M. Wiig, Knowledge Management. The central management focus for intelligent - acting organizations, Arlington 1995.

49 Z. Duniewska, Administracja publiczna w sprawnym państwie rzadzonym dobrym prawem, [w:] Administracja publiczna - aktualne wyzwania, red. L. Zacharko, A. Matan, D. Gregorczyk, Katowice 2015, s. 105 i cyt. tam literatura. 
niespójności unormowań, wadliwej techniki legislacyjnej, inflacji prawa; do tego należy dodać niejednolitość orzecznictwa sądów administracyjnych ${ }^{50}$.

Prawo powinno być nośnikiem aksjologicznych standardów i wdrażać zasady demokratycznego państwa prawnego zgodnie z art. 2 Konstytucji. Dobre prawo powinno być wynikiem przestrzegania przez ustawodawcę konstytucyjnych zasad przy stanowieniu i wprowadzaniu w życie aktów prawnych ${ }^{51}$. J. Zimmermann podkreśla, że:

prawo administracyjne ma służyć dobru człowieka, co można uznać za jego podstawową, w istocie jedyną powinność i sens jego istnienia. Wszystko inne - struktury organizacyjne, związki między tymi strukturami, kompetencje, formy działania, wszelka reglamentacja itd. służą temu jednemu celowi. Nigdy prawo administracyjne nie powinno być tworzone dla samego siebie ani dla administracji, która ma za zadanie służyć człowiekowi lub wspólnotom ludzkim ${ }^{52}$.

M. Zdyb uważa, że do kształtowania się ładu prawnego w Rzeczypospolitej Polskiej kluczowe znaczenie ma niewątpliwie stworzenie czytelnych standardów aksjologicznych, nasyconych wartościami o znaczeniu fundamentalnym. Dla tego procesu duże znaczenie mają historyczne doświadczenia Rzeczypospolitej. Jak pisze dalej autor, pojawiają się na nowo pytania o istotę prawa, jego wartości, bezpieczeństwo prawne, a przez to potrzeba identyfikacji różnych zjawisk destrukcyjnych (inflacja prawa administracyjnego, niedostateczna ochrona praw nabytych, brak właściwych rozwiązań prawnych w tych dziedzinach prawa administracyjnego, które są podstawą życia publicznego, luki w prawie, fetyszyzacja sztucznych wartości, fikcyjność rozwiązań prawnych, niezrozumiałość, niejasność, brak elementarnej przejrzystości tekstów prawnych ${ }^{53}$.

Należy przychylić się do poglądu S. Wronkowskiej, że zmiany w systemie prawa powinny cechować się racjonalnością, trafnością i adekwatnością do potrzeb podmiotów prawa funkcjonujących w zmiennej rzeczywistości. Groźnym zjawiskiem jest fasadowość zmian, to jest takich, które są dokonywane z pobudek populistycznych, w związku z potrzebą odniesienia sukcesów politycznych

50 Szerzej zob. S. Gebethner, Propozycje doskonalenia procesu programowania (planowania) prac legislacyjnych $w$ rzadzie $i$ w Sejmie, [w:] Tworzenie prawa $w$ Polsce - ocena i preferowane kierunki zmian. Raport Rady Legislacyjnej przy Prezesie Rady Ministrów, „Przegląd Legislacyjny” 2006, nr 1, s. 72 n.; J. Wróblewski, Zagadnienia jednolitości i pewności rozumienia tekstów prawa, „Państwo i Prawo” 1966, z. 3; L. Zacharko, Instrumenty lepszego stanowienia prawa administracyjnego — implikacje dla jego stosowania (kilka uwag dyskusyjnych), [w:] Kryzys Prawa Administracyjnego, t. 4. Wyktadnia i stosowania prawa administracyjnego, red. D.R. Kijowski, J. Radwanowicz-Wanczewska, M. Wincenciak, Warszawa 2012, s. 161-162 i cyt. tam literatura; M. Stahl, Z. Duniewska, Legislacja administracyjna. Teoria, orzecznictwo, praktyka, Warszawa 2012.

51 Szerzej zob. T. Zalasiński, Zasada prawidłowej legislacji w poglądach Trybunału Konstytucyjnego, Warszawa 2008.

52 J. Zimmermann, Aksjomaty prawa administracyjnego, Warszawa 2013, s. 77.

53 M. Zdyb, Dylematy tadu prawnego w kontekśsie inflacji i niektórych innych niedoskonałości prawa administracyjnego, [w:] Prawo administracyjne. Dziś i jutro, red. J. Jagielski, M. Wierzbowski, Warszawa 2018, s. 42. 
w krótkim okresie czy potrzebą symbolicznej poprawy obowiązujących przepisów prawa, co działa niestabilizująco na system prawa ${ }^{54}$.

\section{Zakończenie}

Druga połowa XX wieku przynosi istotne zmiany w modelu stosowania metod i technik zarządzania w administracji publicznej. Jakość w zarządzaniu stała się najważniejszą ideą. Wraz ze zmianą otoczenia administracji zmieniają się wskaźniki jakości. W administracji jako organizacji inteligentnej ludzie muszą z sobą współpracować, wymieniać informacje, rozwiązywać problemy. Jak podkreśla się w literaturze, pracownik mający świadomość jakościową, przygotowany do posługiwania się metodami i technikami zarządzania przez jakość, przekonany jest o potrzebie ustawicznego samodoskonalenia ${ }^{55}$. Podnoszenie umiejętności i kompetencji pracowników powinno stać się integralną częścią procesu nowocześnie zarządzanej administracji, która jest obecna we wszystkich sferach życia człowieka ${ }^{56}$.

\section{Bibliografia}

Arczewska M., Raport z badania potrzeb i możliwości regrantingu w ramach projektu „Regranting” jako sposób zwiększenia-zakresu, skali i efektywności realizacji zadań publicznych przez organizacje pozarządowe w gminie i powiecie, Warszawa 2012.

Barczewska-Dziobek A., Partnerstwo publiczno-prywatne, jako zasada w prawie administracyjnym, Rzeszów 2019.

Bendell T., Boulter L., Benchmarking, Kraków 1999.

The Blackwell Encyclopedic Dictionary of Operations Management, red. N. Snack, Oxford 1998.

Blicharz J., Działalność organizacji pozarzadowych (organizacji pożytku publicznego) w ujęciu historycznym, [w:] Prawo organizacji pozarzadowych (organizacji pożytku publicznego). Dziatalność gospodarcza organizacji pozarzadowych, red. J. Blicharz, L. Zacharko, Racibórz 2017.

Blicharz J., Komentarz do ustawy o dziatalności pożytku publicznego i wolontariacie, [w:] Ustawa o działalności pożytku publicznego i wolontariacie. Ustawa o spótdzielniach socjalnych. Komentarz, red. J. Blicharz, Warszawa 2012.

Blicharz J., Znaczenie zasady subsydiarności w kontekście przekazywania wykonywania zadań administracji publicznej organizacjom pozarządowym, „Przegląd Prawa i Administracji” 76, 2007.

54 S. Wronkowska, Kryteria oceny prawa, Torun 2001, s. 38 n. Problemy legislacyjne i niestabilność prawa są szczególnie widoczne w obszarze wdrażania i stosowania nowoczesnych technik i technologii w administracji publicznej; zob. szerzej J. Jankowski, Elektroniczny obrót prawny, Warszawa 2008.

55 M. Bugdoł, Zarządzanie, przez jakość. Zagadnienia społeczne, Opole 2003, s. 28.

56 J. Blicharz, L. Zacharko, op. cit., s. 79. 
Blicharz J., Zacharko L., Globalizm a personalizm wobec administracji publicznej. Studium prawno-administracyjne, Wrocław 2019.

Boć J., Ku administracji jako administracji inteligentnej, [w:] Profesjonalizm $w$ administracji publicznej, red. A. Dębicka, M. Dmochowski, B. Kudrycka, Białystok 2004.

Bugdoł M., Zarzadzanie, przez jakość. Zagadnienia społeczne, Opole 2003.

Cendrowicz D., Pomocniczość jako zasada organizacji pomocy społecznej w samorzadzie terytorialnym, [w:] Sposoby realizacji zadań publicznych, red. B. Dolnicki, Warszawa 2017.

Czaja-Hliniak I., Europejska Karta Samorzadu Lokalnego fundamentem wspótpracy jednostek samorzadu terytorialnego z podmiotami niepublicznymi, [w:] Europejska Karta Samorzadu Lokalnego a prawo samorzadu terytorialnego, red. M. Ofiarska, Szczecin 2015.

Dahlberg A.W., Connell D.W., Landrum J., Budując nowa firmę-w dlugim okresie, [w:] Organizacja przyszłości, red. F. Hesselbein, M. Goldsmith, L. Beckhard, Warszawa 1998.

Dolińska M., Zarządzanie wiedza w uczacej się organizacji, „Organizacja i Kierowanie” 2000, nr 4.

Drummond H., W pogoni za jakością, Warszawa 1998.

Duniewska Z., Administracja publiczna w sprawnym państwie rządzonym dobrym prawem, [w:] Administracja publiczna - aktualne wyzwania, red. L. Zacharko, A. Matan, D. Gregorczyk, Katowice 2015.

Działocha K., Zalasiński T., Określoność przepisów prawa jako przedmiot kontroli konstytucyjności prawa w pogladach Trybunału Konstytucyjnego, [w:] Prawo, parlament i egzekutywa we wspótczesnych systemach rządów. Księga poświęcona pamięci profesora Jerzego Stembrowi$c z a$, red. S. Bożyk, Białystok 2009.

Fleszer D., Realizacja zadań publicznych przez organizacje pozarząowe. Studium administracyjnoprawne, Sosnowiec 2018.

Fundowicz S., Człowiek i administracja publiczna, [w:] Prawość i godność. Ksiegga pamiątkowa w 70. rocznicę urodzin Profesora Wojciecha Laczkowskiego, red. S. Fundowicz, F. Rymarz, A. Gomułowicz, Lublin 2003.

Gebethner S., Propozycje doskonalenia procesu programowania (planowania) prac legislacyjnych w rzadzie i w Sejmie, [w:] Tworzenie prawa w Polsce - ocena i preferowane kierunki zmian.

Raport Rady Legislacyjnej przy Prezesie Rady Ministrów, „Przegląd Legislacyjny” 2006, nr 1.

Gospodarka oparta na wiedzy. Wyzwania dla Polski XXI wieku, red. A. Kukliński, Warszawa 2001.

Grudzewski W., Hejduk I., Zarządzanie wiedza w przedsiębiorstwie, Warszawa 2004.

Hammer M., Champy J., Reengineering w przedsiębiorstwie, Warszawa 1996.

Hamrol A., Mantura W., Zarządzanie jakościa. Teoria i praktyka, Warszawa 1998.

Hliniak-Czaja I., Europejska Karta Samorządu Lokalnego fundamentem wspótpracy jednostek samorzadu terytorialnego z podmiotami niepublicznymi, [w:] Europejska Karta Samorzadu Lokalnego a prawo samorzadu terytorialnego, red. M. Ofiarska, Szczecin 2015.

Jankowski J., Elektroniczny obrót prawny, Warszawa 2008.

Jashapara A., Zarzadzanie wiedza, Warszawa 2006.

Kaplan R.S., Cooper R., Zarządzanie kosztami i efektywnościa, Kraków 2000.

Karlof B., Ostblom S., Benchmarking, Warszawa 1995.

Knosala E., Prawne uktady sterowania w administracji publicznej, Katowice 1998.

Knosala E., Zadania publiczne, formy organizacyjnoprawne ich wykonywania i nowe pojęcia - zakres niektórych problemów do dyskusji nad koncepcja systemu prawa administracyjnego, [w:] Koncepcja systemu prawa administracyjnego, red. J. Zimmermann, Kraków 2007.

Korczak J., Miruć A., Outsourcing komunalny na rzecz organizacji pożytku publicznego w sferze pomocy spolecznej w świetle najnowszych uregulowań prawnych, [w:] Prawne aspekty prywatyzacji, red. J. Blicharz, Wrocław 2012.

Kowalczyk A., Nogalski B., Zarządzanie wiedzą. Koncepcje i narzędzia, Warszawa 2007.

Leś E., Od filantropii do pomocniczości. Studium porównawcze rozwoju i działalności organizacji społecznych, Warszawa 2000. 
Lisowski P., Organizacja prawna administracji wobec przemian cywilizacyjnych, [w:] Wpływ przemian cywilizacyjnych na prawo administracyjne i administracje publiczna, red. J. Zimmermann, P. Suwaj, Warszawa 2013.

Miruć A., Zasada pomocniczości jako podstawa realizacji zadań publicznych z zakresu pomocy społecznej, [w:] Sposoby realizacji zadań publicznych, red. B. Dolnicki, Warszawa 2017.

Morawski M., Zarzadzanie wiedza - ujęcie systemowe, „Organizacja i Kierowanie” 2006, nr 4.

Nogalski B., Benchmarking metoda usprawniania procesów pracy administracji samorzadowej, [w:] Prawne i finansowe aspekty funkcjonowania samorzadu terytorialnego, t. 1. Prawo samorzadowe i administracyjne, red. S. Dolata, Opole 2000.

Nogalski B., Zduńczyk K., Benchmarking jako przejaw kultury organizacyjnej, [w:] Kultura organizacyjna - duch organizacji, red. B. Nogalski et al., Bydgoszcz 1988.

Pakuła A., Samorząd terytorialny a działalność pożytku publicznego, [w:] Samorzad terytorialny III Rzeczypospolitej Polskiej. Materiały z konferencji z okazji 15-lecia samorzadu terytorialnego w III Rzeczypospolitej, red. J. Korczak, Wrocław 2005.

Prawne regulacje działania organizacji pozarzadowych, red. Irisha L., Simon K., Kushena R., 1999. Prawo administracyjne, red. J. Boć, Wrocław 2000.

Rzeszutek M., System jakości a zarządzanie zasobami ludzkimi, „Problemy Jakości” 1998, nr 6.

Sankowski B., ISO jako narzędzie zarządzania, „Problemy Jakości” 2015, nr 3.

Siennicka A., Nowelizacja ustawy o działalności organizacji pożytku publicznego $i$ wolontariacie, „Biuletyn” 2010, nr 1.

Skoczylas A., Działalność uchwałodawcza Naczelnego Sąu Administracyjnego, Warszawa 2004.

Stahl M., Duniewska Z., Legislacja administracyjna. Teoria, orzecznictwo, praktyka, Warszawa 2012.

Teese J.D., Pisano G., Shuen A., Dynamic capabilities and strategic management, „Strategic Management Journal" 18, 1997, nr 7.

Wejcman Z., O pomocniczości i innych fundamentalnych zasadach wspótpracy, [w:] Partnerstwo w praktyce. System wspólpracy samorządów lokalnych z organizacjami pozarządowymi, red. M. Bielawski, A. Jakimowicz, Elbląg 2007.

Wiig K.M., Knowledge management. The central management focus for intelligent - acting organizations, Arlington 1995.

Wronkowska S., Kryteria oceny prawa, „Studia Iuridica Toruniensia”, Toruń 2001.

Wronkowska S., Na czym polega dobra legislacja?, „Przegląd Legislacyjny” 2002, nr 1.

Wróblewska-Jachna J., Misja organizacji pozarzadowych w spoteczeństwie obywatelskim, [w:] Prawo organizacji pozarzadowych (organizacji pożytku publicznego). Działalność gospodarcza organizacji pozarządowych, red. J. Blicharz, L. Zacharko, Racibórz 2017.

Wróblewski J., Zagadnienia jednolitości i pewności rozumienia tekstów prawa, „Państwo i Prawo” 1966, z. 3.

Zacharko L., Dylematy nauki administracji - Problemy dyskusyjne, [w:] Stan i kierunki rozwoju nauk administracyjnych, red. A. Błaś, J. Boć, Wrocław 2014.

Zacharko L., Instrumenty lepszego stanowienia prawa administracyjnego — implikacje dla jego stosowania (kilka uwag dyskusyjnych), [w:] Kryzys Prawa Administracyjnego, t. 4. Wykładnia i stosowania prawa administracyjnego, red. D.R. Kijowski, J. Radwanowicz-Wanczewska, M. Wincenciak, Warszawa 2012.

Zacharko L., Uspołecznienie procesu administrowania — przyczynek do dyskusji, [w:] Nowe problemy badawcze w teorii prawa administracyjnego, red. J. Boć, A. Chajbowicz, Wrocław 2009.

Zacharko L., Zacharko A., Organizacje pozarzadowe, jako instytucjonalne formy nacisku na decydentów politycznych, „Przegląd Prawa Publicznego” 2016, nr 6-7.

Zalasiński T., Zasada prawidłowej legislacji w pogladach Trybunału Konstytucyjnego, Warszawa 2008.

Zalewski A., Nowe zarządzanie publiczne w polskim samorzadzie terytorialnym, Warszawa 2007. 
Zarzadzanie wiedza w przedsiębiorstwie, red. B. Wawrzyniak, Warszawa 2003.

Zdyb M., Dylematy tadu prawnego w kontekśsie inflacji i niektórych innych niedoskonałości prawa administracyjnego, [w:] Prawo administracyjne. Dziś i jutro, red. J. Jagielski, M. Wierzbowski, Warszawa 2018.

Zieliński W., Misja administracji publicznej a motywy inicjowania zmian, „Przegląd Organizacji” 2007, nr 11.

Zimmermann J., Aksjomaty prawa administracyjnego, Warszawa 2013.

\section{Public administration managed in a modern way - a few reflections}

\section{Summary}

The aim of the article is to show the challenges that public administration faces in the field of management. The specificity of the provided services enforces a proper and orderly manner of action, whose main goal should be quality. The customer is the most important person in any organization. Quality management in administration implies the implementation of modern techniques and methods of operation, such as: benchmarking, benchlearning, reengineering, outsourcing, or regranting.

Keywords: quality management, benchmarking, benchlearning, outsourcing, knowledge management, intelligent organization. 